\title{
Interference Standard Applied to Sulfur Determination in Biodiesel Microemulsions by ICP-QMS
}

\author{
Renata S. Amais, George L. Donati and Joaquim A. Nóbrega* \\ Group of Applied Instrumental Analysis, Department of Chemistry, \\ Federal University of São Carlos, CP 676, 13560-970 São Carlos-SP, Brazil
}

\begin{abstract}
A determinação de enxofre por espectrometria de massa com plasma acoplado indutivamente (ICP-MS) não é trivial, especialmente devido a intensas interferências espectrais causadas por íons poliatômicos como ${ }^{16} \mathrm{O}_{2}^{+},\left({ }^{16} \mathrm{OH}\right)_{2}{ }^{+},{ }^{14} \mathrm{~N}^{16} \mathrm{OH}_{2}{ }^{+} \mathrm{e}^{14} \mathrm{~N}^{18} \mathrm{O}^{+}$. Neste trabalho, espécies de argônio naturalmente presentes no plasma (padrões de interferência, IFS) são usadas para minimizar interferências espectrais na determinação de enxofre em microemulsões de biodiesel. Um método de calibração externa utilizando as razões entre os sinais analíticos e dos IFS é empregado em todas as determinações. Os limites de detecção (LOD) calculados para as razões 32/36, 34/36, 34/37 e $34 / 38$ foram 4,0, 1,0, 1,0 e $0,8 \mathrm{mg} \mathrm{L}^{-1}$, respectivamente. Um material de referência certificado (Lubricating Oil, SRM 1848) e testes de adição e recuperação em amostras de biodiesel foram empregados para avaliar a exatidão do método. As recuperações variaram de 77 a $105 \%$ a partir do emprego de qualquer espécie IFS $\left({ }^{36} \mathrm{Ar}^{+},{ }^{36} \mathrm{ArH}^{+}\right.$ou $\left.{ }^{38} \mathrm{Ar}^{+}\right)$.
\end{abstract}

Determining sulfur by inductively coupled plasma mass spectrometry (ICP-MS) is not a trivial task especially due to the intense spectral interferences caused by polyatomic ions such as ${ }^{16} \mathrm{O}_{2}{ }^{+},\left({ }^{16} \mathrm{OH}\right)_{2}{ }^{+}{ }^{14} \mathrm{~N}^{16} \mathrm{OH}_{2}{ }^{+}$and ${ }^{14} \mathrm{~N}^{18} \mathrm{O}^{+}$. In this work, argon species naturally present in the plasma (interference standards, IFS) are used to minimize spectral interferences on sulfur determination in biodiesel microemulsions. An external calibration method using ratios between analytical and IFS signals is employed in all determinations. The limits of detection (LOD) calculated for the 32/36, 34/36, 34/37 and 34/38 signal ratios were 4.0, 1.0, 1.0 and $0.8 \mathrm{mg} \mathrm{L}^{-1}$, respectively. A standard reference material (Lubricating Oil, SRM 1848) and spiking studies in biodiesel samples were employed to check the method accuracy. Recoveries varied from 77 to $105 \%$ while using any of the IFS probes $\left({ }^{36} \mathrm{Ar}^{+},{ }^{36} \mathrm{ArH}^{+}\right.$or $\left.{ }^{38} \mathrm{Ar}^{+}\right)$.

Keywords: IFS species, spectral interferences, mass spectrometry, biodiesel, microemulsions

\section{Introduction}

Along with development of motor vehicles and pronounced increase of world population, the high fuel consumption has caused serious environmental problems especially due to large $\mathrm{CO}, \mathrm{NO}_{\mathrm{x}}$ and metal emissions. ${ }^{1,2}$ Sulfur compounds emitted by fuel burning are also an important issue that causes atmospheric pollution and health problems, and it has high impact on climate and contributes significantly to acid rain. ${ }^{2}$

In recent years, there is a trend to reduce the sulfur content in fuels. ${ }^{2}$ One alternative to reduce $\mathrm{S}$ and other pollutants emission is the addition of biodiesel to fossil diesel. ${ }^{3,4}$ Biodiesel is an alternative fuel obtained through transesterification

*e-mail:djan@terra.com.br reaction of vegetable oils or animal fats with short chain alcohols such as methanol., ${ }^{5,6}$ Governmental agencies have also restricted maximum sulfur content allowed in biodiesel. According to EN 14214 and ASTM D6751, maximum sulfur contents in biodiesel samples are 10 and $500 \mathrm{mg} \mathrm{kg}^{-1}$, respectively. ${ }^{7}$ Thus, it is important the development of accurate and sensitive methods for $\mathrm{S}$ determination.

Determination of sulfur in fuels is still not an easy task. ASTM D5453 recommends the direct sulfur determination in liquid hydrocarbons such as naphtha, gasoline, diesel and biodiesel by ultraviolet fluorescence spectrometry (UV fluorescence). In this case, sample is burned and sulfur is oxidized in oxygen atmosphere; the determined specie is $\mathrm{SO}_{2} .{ }^{8}$ However, special equipment is required for this analysis. ${ }^{9}$ Other official standard methods are also recommended for sulfur determination in fuels. 
ASTM D2622 establishes the determination of sulfur in petroleum products by wavelength dispersive X-ray fluorescence spectroscopy (WDXFS), and ASTM D3120 is based on the oxidative high temperature pyrolysis of the sample and detection by microcoulometry titration. ${ }^{10}$ Nevertheless, ethanol in concentrations higher than $8.6 \%$ $(\mathrm{m} / \mathrm{m})$ is an important interfering species in determinations based on ASTM D2622. Therefore, the application of this method in gasoline commercialized in Brazil is difficult because it requires matrix-matching. On the other hand, ASTM D3120 high limits of detection and low sample throughput limit its application in routine analysis. ${ }^{10}$

Several advantages such as high sensitivity, multielement and isotope measurement capability and high throughput promoted inductively coupled plasma quadrupole mass spectrometry (ICP-QMS) as one of the most powerful and versatile instrumental technique in analytical chemistry. ${ }^{11,12}$ Despite of its advantages, its application to some elements is limited by polyatomic ions formed in the plasma causing spectral overlaps. ${ }^{13}$ The main isotopes of sulfur, ${ }^{32} \mathrm{~S}^{+}(95.02 \%)$ and ${ }^{34} \mathrm{~S}^{+}(4.21 \%)$, are severely affected by ${ }^{16} \mathrm{O}_{2}{ }^{+},\left({ }^{16} \mathrm{OH}\right){ }_{2}{ }^{+},{ }^{14} \mathrm{~N}^{16} \mathrm{OH}_{2}{ }^{+}$and ${ }^{14} \mathrm{~N}^{18} \mathrm{O}^{+}$. In addition to such interferences, the high ionization potential of $\mathrm{S}(10.36 \mathrm{eV})$, which results in a low ionization efficiency in the plasma (about 14\%), contributes to the lower sensitivity of this element in ICP-QMS..$^{914,15}$

Despite these difficulties, several refinements and improvements have been made on ICP-MS since its introduction in the 1980s. Post-plasma correction methods based on collision and/or reaction processes for interfering ion suppression have been successfully employed. ${ }^{16}$ Among the commercial devices, collision/reaction cell (CRC), dynamic reaction cell (DRC) and octapole reaction system (ORS) technologies present a pressurized cell before mass analyzer, and gases are introduced into the cell to promote collision/reaction processes that can minimize or eliminate spectral interferences. ${ }^{16,17}$ In these approaches, the formation of undesirable species is possible and they must be eliminated. It is performed by two modes: either kinetic energy or mass discrimination, according to multipole inside the cell and their mechanisms. ${ }^{16,18,19}$ Collision and reaction interface (CRI), a different approach for reducing interfering polyatomic ions, is based on introduction of reaction/collision gases through cones either at the plasma region or the expansion zone located in the vacuum region. ${ }^{20,21}$ According to Pereira et al. ${ }^{22}$ the $\mathrm{H}_{2}$ gas introduction through the skimmer cone was efficient to reduce spectral interferences on arsenic determination, however, an intense loss of signal intensity was observed.

Recently reported by Donati et al., ${ }^{23}$ interference standard (IFS) method has demonstrated efficiency to improve the accuracy in ICP-QMS determinations. This method requires neither instrumental modification nor addition of gases into the plasma or interfaces to minimize spectral interferences. Because the interfering signal is usually high, small variations on it can severely depreciate accuracy. Such as described by Donati et al. ${ }^{23}$ if interfering signal is 100 -fold higher than the analytical signal, a variance of $+1 \%$ in it can result in a $200 \%$ recovery. The IFS method is based on the idea that IFS species $\left({ }^{36} \mathrm{Ar}^{+},{ }^{36} \mathrm{ArH}^{+}\right.$and ${ }^{38} \mathrm{Ar}^{+}$, argon species naturally present in the plasma) and interfering ion may experience similar variances during the analysis, thus the effect of the interfering signal on analytical signal can be minimized simply by dividing the analytical signal (analyte plus interference) by the IFS signal. ${ }^{23}$

Accuracy for As, K, P and Si determinations was achieved in water, apple leaves and typical diet reference materials. ${ }^{23}$ It was also demonstrated the application of IFS method for $\mathrm{Fe}, \mathrm{Mn}$ and $\mathrm{S}$ determinations in food samples for the first time. ${ }^{24}$

According to Amais et al.,${ }^{24}$ for sulfur determination at $\mathrm{m} / \mathrm{z} 32$ without IFS method, not even a calibration curve was obtained. On the other hand, by employing ${ }^{38} \mathrm{Ar}^{+}$as IFS, accurate determinations were achieved. Thus, the IFS method could contribute to expand ICP-QMS applications by improving accuracy in complex matrix determinations.

In both cited works, ${ }^{23,24}$ the IFS method was employed for element analyses in acid digested samples. However, several elemental fuel analyses have recently been carried out by emulsion or microemulsion preparation. ${ }^{25-28}$ Biodiesel microemulsion preparation was performed for $\mathrm{Cd}, \mathrm{Co}, \mathrm{Cu}$, $\mathrm{Mn}, \mathrm{Ni}, \mathrm{Pb}$, Ti and $\mathrm{Zn}$ determinations by ICP-QMS. ${ }^{27}$ According to the authors, microemulsion is a simple and fast sample preparation procedure and calibration curve can be prepared by using inorganic standards. Moreover, sample stability and no use of carcinogenic organic solvent are attractive in microemulsion preparation. In this present work, the IFS method is applied for sulfur determination in biodiesel microemulsions. By the first time, this strategy is applied for fuel analyses in an organic solvent medium.

\section{Experimental}

\section{Reagents and materials}

Aqueous solutions were prepared with analytical grade chemicals and deionized water (resistivity higher than 18.2 $\mathrm{M} \Omega \mathrm{cm}$ ) obtained from a Milli-Q water purification system (Millipore, Bedford, MA, USA). Nitric acid (Merck, Darmstadt, Germany) was distilled in quartz sub-boiling still (Milestone, Sorisole, Italy). Polyoxylene (10) 
octylphenil ether (Triton X-100) (Acros Organics, Morris Plains, NJ, USA), xylene (Mallinckrodt Baker, Xalostoc, Mexico), n-propanol and light mineral oil (Tedia, Rio de Janeiro-RJ, Brazil) were used without previous purification. Sulfur calibration solutions were prepared by dilution from a $1000 \mathrm{mg} \mathrm{L}^{-1} \mathrm{~S}$ stock solution (Qhemis High Purity, Hexis, São Paulo-SP, Brazil). All the glassware was kept in a $10 \%(\mathrm{v} / \mathrm{v})$ nitric acid solution for $24 \mathrm{~h}$ and rinsed with ultra-pure water.

\section{Apparatus}

An inductively coupled plasma mass spectrometer (ICP-MS, Varian 820-MS, Mulgrave, Australia) with quadrupole mass analyzer was used in all experiments. The sample introduction system was composed of concentric nebulizer and double path spray chamber (Scott type) made with perfluoroacetate (PFA) and an automatic sampler (SPS3, Varian). An additional gas flow controller (AGM-1, Varian) for adding oxygen (99.99\%, White Martins, Sertãozinho-SP, Brazil) as auxiliary gas in the ICP was employed. Table 1 presents instrumental and operating conditions. The mass-to-charge ratios $(\mathrm{m} / \mathrm{z})$ monitored were 32 and 34 for $\mathrm{S}$ measurements and 36,37 and 38 for ${ }^{36} \mathrm{Ar}^{+}$, ${ }^{36} \mathrm{ArH}^{+}$and ${ }^{38} \mathrm{Ar}^{+}$, the IFS species. IFS method was used to minimize interfering signal contribution, from polyatomic ions such as ${ }^{16} \mathrm{O}_{2}{ }^{+},{ }^{14} \mathrm{~N}^{16} \mathrm{OH}_{2}^{+},\left({ }^{16} \mathrm{OH}\right)_{2}{ }^{+}$and ${ }^{15} \mathrm{~N}^{18} \mathrm{OH}^{+}$, on the analyte signal by dividing the total analytical signal intensity by IFS signal intensity.

Table 1. ICP-QMS operating conditions

\begin{tabular}{lc}
\hline \multicolumn{2}{c}{ Operating conditions } \\
\hline Generator frequency $(\mathrm{MHz})$ & 27 \\
Plasma gas flow rate / $\left(\mathrm{L} \mathrm{min}{ }^{-1}\right)$ & 18.0 \\
Auxiliary gas flow rate / $\left(\mathrm{L} \mathrm{min}^{-1}\right)$ & 1.8 \\
Nebulizer gas flow rate / $\left(\mathrm{L} \mathrm{min}^{-1}\right)$ & 1.0 \\
Sheath gas flow rate / $\left(\mathrm{L} \mathrm{min}^{-1}\right)$ & 0.21 \\
Oxygen gas flow rate / $\left(\mathrm{L} \mathrm{min}^{-1}\right)$ & 162.5 \\
Peristaltic pump rate / $\mathrm{rpm}$ & 7 \\
Sampling depth / mm & 5.5 \\
RF power / kW & 1.4 \\
Points per peak & 3 \\
Scans per replicate & 3 \\
Replicate per sample & 5 \\
Dwell time / ms & 1 \\
Spray chamber temperature / ${ }^{\circ} \mathrm{C}$ & 2 \\
\hline
\end{tabular}

\section{Microemulsion sample preparation}

The samples were prepared following the procedure previously described by Amais et al.: ${ }^{27} 0.5 \mathrm{~mL}$ of $20 \%(\mathrm{v} / \mathrm{v})$ $\mathrm{HNO}_{3}$ and $0.5 \mathrm{~mL}$ of Triton $\mathrm{X}-100$ were added to $1.0 \mathrm{~mL}$ of biodiesel. Then, n-propanol was added to the mixture to a final volume of $10 \mathrm{~mL}$. The mixture was homogenized using a vortex mixer for $2 \mathrm{~min}$ and transparent microemulsions were obtained. The same procedure was applied to prepare the blank and standard reference solutions used in the external calibration method. In these cases, $0.2 \mathrm{~mL}$ of mineral oil was used to simulate the biodiesel matrix, and different volumes of an inorganic sulfur stock solution were added to the mixture. A standard reference material (Lubricating Oil, SRM 1848) and spiking studies in biodiesel samples were employed to check the method accuracy. Because it was not possible to obtain a stable microemulsion from pure lubricating oil, approximately $0.1 \mathrm{mg}$ of SRM 1848 was dissolved in $10 \mathrm{~mL}$ of xylene and microemulsions were prepared from $0.25 \mathrm{~mL}$ aliquots of this solution.

\section{Results and Discussion}

\section{Plasma stability}

Since the microemulsion introduction makes it difficult the determinations in ICP-MS due to high organic load samples, oxygen gas was added as an auxiliary gas to the plasma in order to minimize carbon build-up deposits onto the sampler and skimmer cones and to minimize the background signal. ${ }^{29}$

The oxygen gas flow rate was chosen considering the total elimination of Swan band emissions in the plasma (162.5 $\left.\mathrm{mL} \mathrm{min}^{-1}\right)$, which can be visually detected due to an intense green color. It is important to emphasize that the increase of oxygen gas flow rate to $205 \mathrm{~mL} \mathrm{~min}^{-1}$ could reduce in $\mathrm{ca}$. $7 \%$ the ${ }^{13} \mathrm{C}^{+}$signal intensity. On the other hand, since the increase of oxygen gas flow rate can increase isobaric interferences on the sulfur determinations, it depreciated the accuracy of the proposed method.

In order to guarantee the plasma stability, a high radiofrequency applied power $(1.4 \mathrm{~kW})$ was also used in all determinations. ${ }^{29}$ Moreover, according to the literature, the reduction of spray chamber temperature can reduce oxides formation and the amount of solvent introduced into the plasma, which improve its stability. ${ }^{30}$ However, it was observed poor accuracy when the spray chamber temperature was decreased from 2 to $-5^{\circ} \mathrm{C}$.

Effect of IFS strategy on accuracy of sulfur determination in biodiesel microemulsions

The interference standard method was recently described as a new approach to minimize polyatomic interference and to improve accuracy in ICP-QMS 
Table 2. Effect of IFS strategy on accuracy of sulfur determination in biodiesel samples by ICP-QMS

\begin{tabular}{|c|c|c|c|c|c|c|}
\hline Sample & Reference & Without IFS & $32 / 36$ & $34 / 36$ & $34 / 37$ & $34 / 38$ \\
\hline Lubricating Oil SRM $1848 /$ mass $\%$ & $2.3270 \pm 0.0043$ & - & $1.79 \pm 0.27$ & $2.32 \pm 0.08$ & $2.30 \pm 0.16$ & $2.08 \pm 0.17$ \\
\hline Biodiesel A / $\left(\mathrm{mg} \mathrm{L}^{-1}\right)$ & 5.0 & - & $5.07 \pm 0.70$ & $4.96 \pm 0.17$ & $5.24 \pm 0.33$ & $4.44 \pm 0.32$ \\
\hline Biodiesel B / (mg L-1 $)$ & 5.0 & $9.53 \pm 0.52 *$ & - & $4.63 \pm 0.39$ & $5.25 \pm 0.13$ & $4.63 \pm 0.30$ \\
\hline
\end{tabular}

* Result presented for ${ }^{34} \mathrm{~S}^{+}$

determinations. According to Donati et al. ${ }^{23}$ IFS species ${ }^{\left({ }^{36}\right.} \mathrm{Ar}^{+},{ }^{36} \mathrm{ArH}^{+}$and $\left.{ }^{38} \mathrm{Ar}^{+}\right)$are directly or indirectly related to interfering ion, however, the mechanism is not completely elucidated. Moreover, comparable signal intensities and same behavior in plasma of IFS species and interfering ion are parameters that affect IFS efficiency.

Considering that the interfering signal contribution to the analytical signal at $\mathrm{m} / z, 32$ and 34 for S measurement is appreciable, small variances in the polyatomic species formation can result in a significant loss of accuracy. Thus, ratios between analyte and IFS signal intensities were used for blank, standard and sample microemulsions. The IFS method and external calibration were employed in all determinations. The effect of IFS strategy on accuracy of sulfur determination in microemulsion was evaluated by spike experiments with biodiesel samples and lubricating oil certificated reference material (SRM 1848).

As it can be seen in Table 2, poor accuracy was obtained in all determinations without the IFS approach. In some cases, severe spectral interferences prevented it even from obtaining linear analytical calibration curves and none result was obtained. Determining S by ICP-QMS in such complex matrices is not a trivial task. Inadequate recoveries were obtained even by monitoring the ${ }^{34} \mathrm{~S}$ isotope, which is less affected by spectral interferences than ${ }^{32} \mathrm{~S}$. On the other hand, good agreement was observed between determined and reference values while using any of the IFS probes $\left({ }^{36} \mathrm{Ar}^{+},{ }^{36} \mathrm{ArH}^{+}\right.$and $\left.{ }^{38} \mathrm{Ar}^{+}\right)$in ${ }^{34} \mathrm{~S}^{+}$determinations. Recoveries varied from 76.9 to $105 \%$. In addition, the sulfur content obtained by the developed method is in agreement (confidence interval at a 95\% using $t$-test) with those values defined by the certified reference material (SRM 1848) and reference sulfur content.

It is possible to observe in Figure 1a significant differences of signal intensities at $\mathrm{m} / \mathrm{z} 34$ for sample solution and its respective standard solution in the calibration curve. On the other hand, the polyatomic interference was minimized by employing ${ }^{36} \mathrm{Ar}^{+}$as IFS for determinations at $\mathrm{m} / \mathrm{z}, 34$ (Figure 1b). No significant differences were observed at a $95 \%$ confidence level between sample measurements and its respective standard solution in the calibration curve. According to Figure 2a, poor accuracy was obtained comparing sample solution signal and its reference standard solution. On the other hand, comparable signal intensities (mean \pm 1 standard deviation, $\mathrm{n}=5$ ) were obtained after dividing the analytical signal at $m / z 34$ by the IFS at $m / z 38$, as shown in Figure 2b. These results demonstrate that IFS method was effective to improve accuracy on sulfur determinations and it is essential for performing analysis of biodiesel samples introduced as microemulsions.
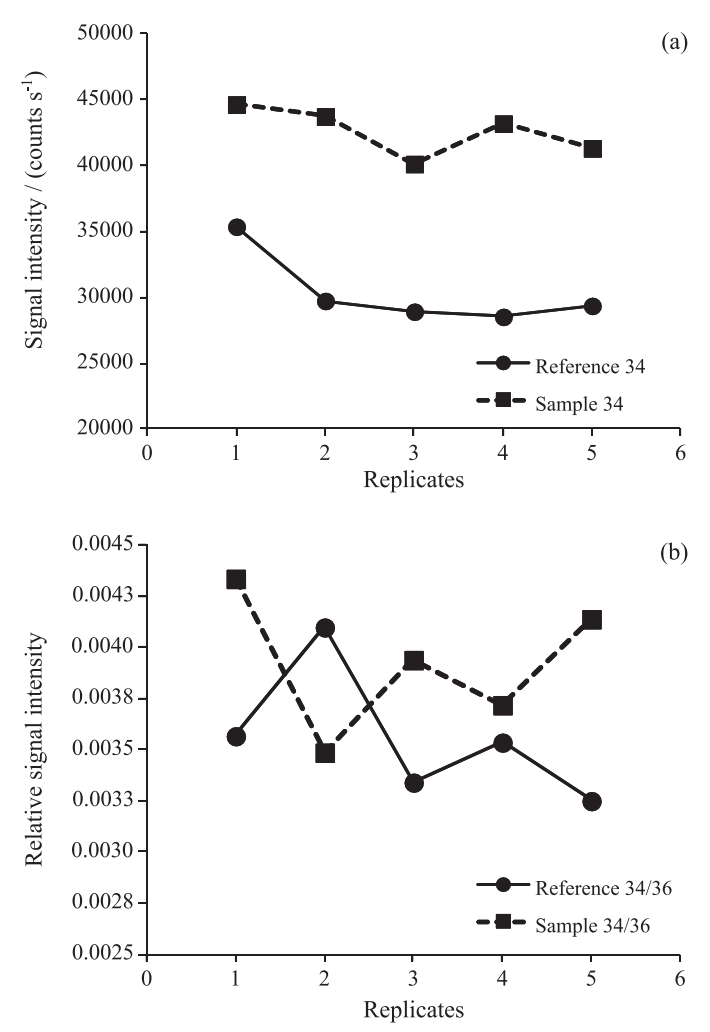

Figure 1. Signal intensities for sample and its respective standard reference solution in the calibration curve (both containing $5 \mathrm{mg} \mathrm{L}^{-1}$ ) without IFS correction (a) and after correction by ${ }^{36} \mathrm{Ar}^{+}$(IFS) (b).

According to a previous work, which determined sulfur in different food samples by employing IFS method, the ${ }^{38} \mathrm{Ar}^{+}$probe presented the best results. ${ }^{24}$ In the present work, however, all IFS species were adequate to improve accuracy probably because biodiesel microemulsions are completely different from digested food samples, consequently resulting in different interactions between IFS and plasma species. It is interesting to note that the 

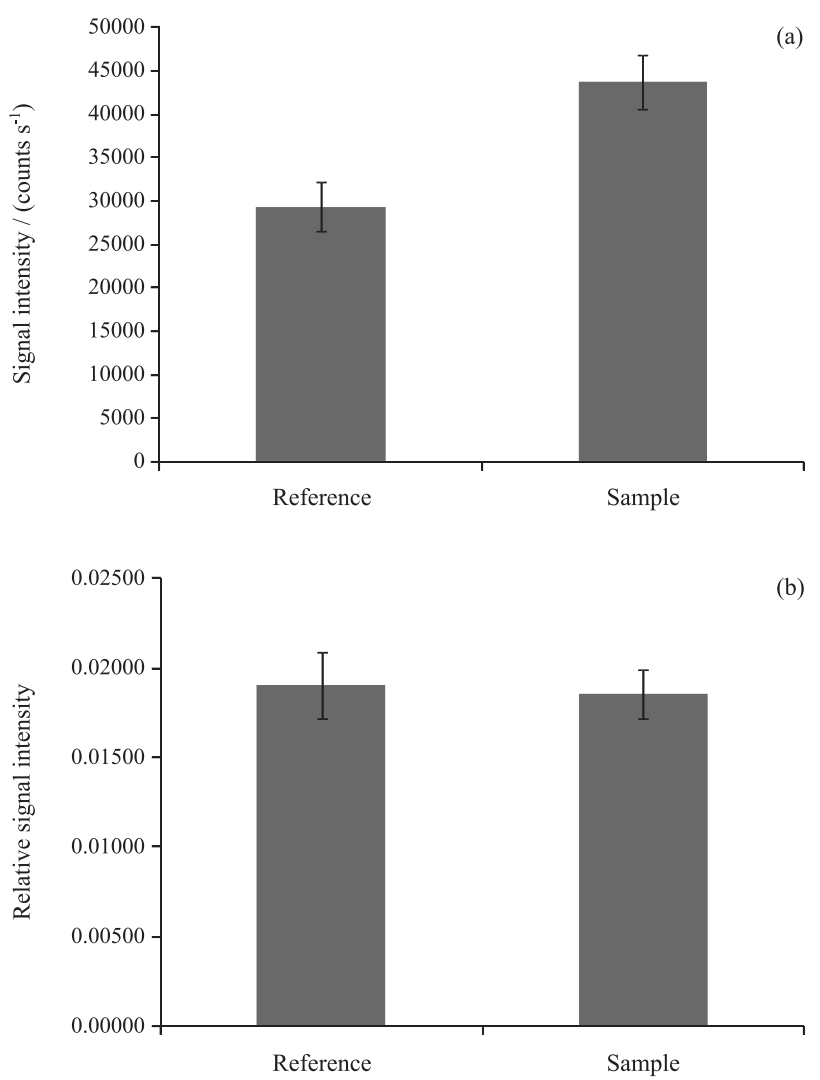

Figure 2. Representation of ${ }^{34} \mathrm{~S}^{+}$signal correction by ${ }^{38} \mathrm{Ar}^{+}$(IFS) (mean \pm standard deviation, $\mathrm{n}=5$ ). Sample microemulsion and its respective standard solution in the calibration curve (both containing $5 \mathrm{mg} \mathrm{L}-1)$ (a) without, and (b) with IFS correction.

${ }^{36} \mathrm{Ar}^{+}$probe was effective even for determinations of $\mathrm{S}$ at $\mathrm{m} / \mathrm{z}$ 32. This behavior can be explained considering that signal intensities at $\mathrm{m} / \mathrm{z} 32$ and 36 are more comparable than other IFS species, as previously discussed. ${ }^{23,24}$

An interesting behavior observed for 20 consecutive measurements of the blank microemulsion solution was that the same signal variations was observed at $\mathrm{m} / \mathrm{z} 32$ and 34 , as can be seen in Figures $3 a$ and $3 b$. The correlation coefficient between signal intensities at $\mathrm{m} / \mathrm{z} 32$ and 34 of the blank microemulsion solution was 0.9726 . Although the interfering ions at $\mathrm{m} / \mathrm{z}, 32$ and 34 are different $\left({ }^{16} \mathrm{O}_{2}^{+}\right.$, $\left({ }^{16} \mathrm{OH}\right)_{2}^{+},{ }^{14} \mathrm{~N}^{16} \mathrm{OH}_{2}{ }^{+}$and $\left.{ }^{14} \mathrm{~N}^{18} \mathrm{O}^{+}\right)$, considering the results presented in Figures $3 a$ and $3 b$, it could be inferred that the interfering species in both cases have the same major source, which is probably oxygen from the solvent and nitrogen from $\mathrm{HNO}_{3}$ used in the microemulsion preparation and from the atmospheric air. According to Yu et al.,$^{14}$ species of oxygen at $m / z 32,33$ and 34 are primarily from water. Moreover, the non-solvent sources of oxygen interfering ion were also investigated by these authors ${ }^{14}$ and the spectral background was significantly lower in dry plasma conditions.

Figure 4 shows the effects of different media (dry plasma, $\mathrm{HNO}_{3} 1 \% \mathrm{v} / \mathrm{v}$, and microemulsion) on the background signal
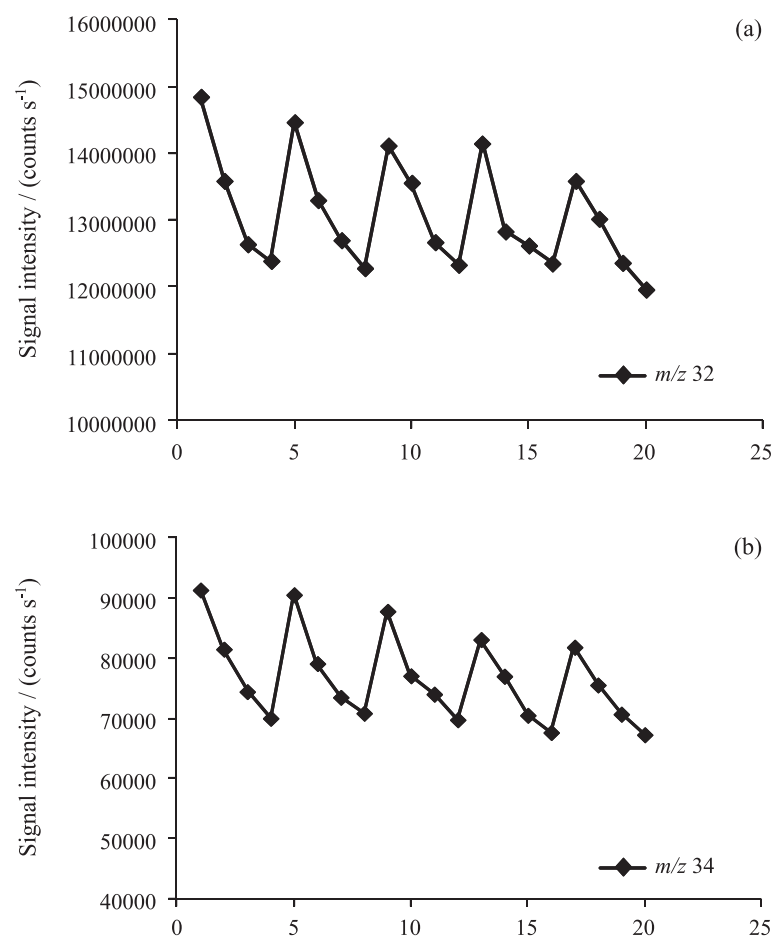

Figure 3. Signal intensity variances observed for 20 consecutive measurements of blank microemulsion solution at $\mathrm{m} / \mathrm{z}, 32$ (a) and 34 (b).

intensity at $m / z 32$ and 34 . As it can be observed, the major source of spectral interferences is probably the solvent (water or n-propanol). For the microemulsion, for example, it was observed approximately $75 \%$ increase in signal intensity when compared with the dry plasma at $m / z, 34$. This increase of background signal intensity is probably caused by polyatomic interfering ions formed in the plasma. Considering the significant difference in plasma in dry plasma conditions or while $\mathrm{HNO}_{3} 1 \% \mathrm{v} / \mathrm{v}$ or microemulsion solutions were introduced, the plasma energy available is an important issue in background signal intensity variations. It is interesting to note (Figures $4 \mathrm{a}$ and $4 \mathrm{~b}$ ) that while using IFS method, background signal intensities in different media are comparable. This behavior may be another evidence of the IFS method efficiency to minimizing spectral interferences and differences in plasma energy conditions.

\section{Analytical figures of merits}

According to Table 3, IFS method presented a slight improvement on background equivalent concentration (BEC) and relative standard deviation (RSD) values for 10 measurements of blank solution thus, consequently limits of detection (LOD) were improved for the 32/36, $34 / 36,34 / 37$ and $34 / 38$ signal ratios. It is important to emphasize that by employing the IFS strategy, the proposed 

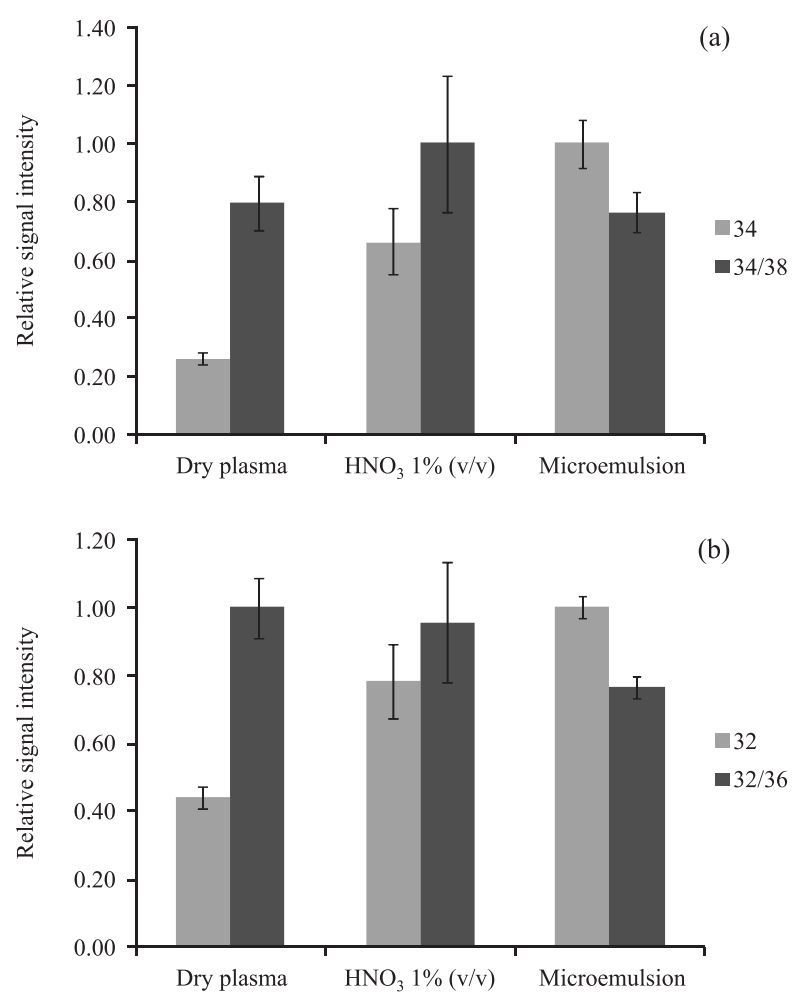

Figure 4. Relative ICP-QMS signal intensities at $\mathrm{m} / \mathrm{z} 34$ (a) and 32 (b) for blank solutions prepared in different media and determined with or without the IFS signal correction (i.e., 34/38 ratio in Figure 4a and 32/36 ratio in Figure 4b).

method is compatible with legislations from different governments and agencies across the world, attending different levels of sulfur restriction, e.g. 500, 50 and $10 \mathrm{mg} \mathrm{kg}^{-1}$ from the United States, Brazil and European Community Legislations, respectively.

Table 3. ICP-QMS analytical performance for $\mathrm{S}$ determination using the IFS method in biodiesel microemulsions

\begin{tabular}{lccc}
\hline $\mathrm{m} / z$ & $\mathrm{BEC} /\left(\mathrm{mg} \mathrm{L}^{-1}\right)$ & $\mathrm{RSD} / \%$ & $\mathrm{LOD}^{\mathrm{a}} /\left(\mathrm{mg} \mathrm{L}^{-1}\right)$ \\
\hline 34 & 30.8 & 9.6 & 9 \\
$32 / 36$ & 23.6 & 5.4 & 4 \\
$34 / 36$ & 4.2 & 8.1 & 1 \\
$34 / 37$ & 10.2 & 4.3 & 1 \\
$34 / 38$ & 3.5 & 7.8 & 0.8 \\
\hline
\end{tabular}

aLimits of detection in microemulsions.

\section{Conclusions}

Accuracy for sulfur determination in biodiesel microemulsions was achieved by employing the IFS method and neither instrumental modification nor post-plasma reaction was used. The IFS correction mechanism is not completely elucidated. However, it is possible that IFS and interfering species are related by thermodynamic equilibrium and by direct or indirect interactions, presenting similar behaviors in the plasma. Thus, the analytical/IFS signal ratio can be used to minimize variations on the overall analytical signal intensity. It was the first time that the IFS method was applied for fuel analyses in an organic solvent medium and it supports the idea that this strategy can be widely applied in different fields of analytical chemistry.

\section{Acknowledgments}

The authors are grateful for grants and fellowships provided by Fundação de Amparo à Pesquisa do Estado de São Paulo (FAPESP - Grants 2006/59083-9, 2010/17387-7 and 2010/50238-5), Conselho Nacional de Desenvolvimento Científico e Tecnológico (CNPq), and Coordenação de Aperfeiçoamento de Pessoal de Nível Superior (CAPES).

\section{References}

1. Ferreira, S. L.; Santos, A. M.; Souza, G. R.; Polito, W. L.; Energy 2008, 33, 1801.

2. Duarte, F. A.; Mello, P. A.; Bizzi, C. A.; Nunes, M. A. G.; Moreira, E. M.; Alencar, M. S.; Motta, H. N.; Dressler, V. L.; Flores, E. M. M.; Fuel 2011, 90, 2158.

3. Panwara, N. L.; Kaushik, S. C.; Kothari, S.; Renewable and Sustainable Energy Rev. 2011, 15, 1513.

4. Woods, G. D.; Fryer F. I.; Anal. Bioanal. Chem. 2007, 389, 753.

5. Pinto, A. C.; Guarieiro, L. L. N.; Rezende, M. J. C.; Ribeiro, N. M.; Torres, E. A.; Lopes, W. A.; de Pereira, P. A. P.; de Andrade, J. B.; J. Braz. Chem. Soc. 2005, 16, 1313.

6. Korn, M. G. A.; Santos, D. C. M. B.; Guida, M. A. B.; Barbosa, I. S.; Passos, M. L. C.; Saraiva, M. L. M. F. S.; Lima, J. L. F. C; J. Braz. Chem. Soc. 2010, 21, 2278.

7. Monteiro, M. R.; Ambrozin, A. R. P.; Lião, L. M.; Ferreira, A. G.; Talanta 2008, 77, 593.

8. American Society for Testing and Materials (ASTM) D5453-09: Standard Test Method for Determination of Total Sulfur in Light Hydrocarbons, Spark Ignition Engine Fuel, Diesel Engine Fuel, and Engine Oil by Ultraviolet Fluorescence.

9. Welz, B.; Lepri, F. G.; Araujo, R. G. O.; Ferreira, S. L. C.; Huang, M. D.; Okruss, M.; Becker-Ross, H.; Anal. Chim. Acta 2009, 647, 137.

10. Santelli, R. E.; Oliveira, E. O.; Carvalho, M. F. B.; Bezerra, M. A.; Freire, A. S.; Spectrochim. Acta, Part B 2008, 63, 800.

11. Becker, J. S.; Inorganic Mass Spectrometry: Principles and Applications, $1^{\text {st }}$ ed.; Wiley: Chichester, 2008.

12. Gomes Neto, J. A.; Silva, J. B. B.; Rodrigues Neto, R.; Curtius, A. J.; Souza, I. G.; Quím. Nova 1998, 21, 405.

13. Thomas, R.; Spectroscopy 2002, 17, 24. 
14. Yu, L.L.; Kelly, W. R.; Fassett, J. D.; Vocke, R. D.; J. Anal. At. Spectrom. 2001, 16, 140.

15. Guillong, M.; Latkoczy, C.; Seo, J. H.; Günther, D.; Heinrich, C. A.; J. Anal. At. Spectrom. 2008, 23, 1581.

16. Thomas, R.; Spectroscopy 2002, 17, 42.

17. D’Ilio, S.; Violante, N.; Majorani, C.; Petrucci, F.; Anal. Chim. Acta 2011, 698, 6.

18. Tanner, S. D.; Baranov, V. I.; Bandura, D. R.; Spectrochim. Acta, Part B 2002, 57, 1361.

19. Bandura, D. R.; Baranov, V. I.; Tanner, S. D.; Fresenius J. Anal. Chem. 2001, 370, 454.

20. Fialho, L. L.; Pereira, C. D.; Nóbrega, J. A.; Spectrochim. Acta, Part B 2011, 66, 189.

21. Kalinitchenko, I.; Wang, X.; Sturman, B.; Spectroscopy 2008 , $23,38$.

22. Pereira, C. D.; Garcia, E. E.; Silva, F. V.; Nogueira, A. R. A.; Nóbrega, J. A.; J. Anal. At. Spectrom. 2010, 25, 1763.

23. Donati, G. L.; Amais, R. S.; Nóbrega, J. A.; J. Anal. At. Spectrom. 2011, 26, 1827.

24. Amais, R. S.; Donati, G. L.; Nóbrega, J. A.; Anal. Chim. Acta 2011, 706, 223.
25. Souza, R. M.; Leocádio, L. G.; Silveira, C. L. P.; Anal. Lett. 2008, 41, 1615.

26. Dos Santos, D. S. S.; Teixeira, A. P.; Korn, M. G. A.; Teixeira, L. S. G.; Spectrochim. Acta, Part B 2006, 61, 592.

27. Amais, R. S.; Garcia, E. E.; Monteiro, M. R.; Nogueira, A. R. A.; Nóbrega, J. A.; Microchem. J. 2010, 96, 146.

28. Young, C. G.; Amais, R. S.; Schiavo, D.; Garcia, E. E.; Nóbrega, J. A.; Jones, B. T.; Talanta 2011, 84, 995.

29. Edlund, M.; Visser, H.; Heitland, P.; J. Anal. At. Spectrom. 2002, 17, 232.

30. Van Heuzen, A. A. In Applications of Inductively Coupled Plasma Mass Spectrometry; Date, A. R.; Gray, A. L., eds.; Blackie Academic \& Professional: London, 1989, ch. 7.

Submitted: November 22, 2011

Published online: March 20, 2012

FAPESP has sponsored the publication of this article. 